\title{
Rangelia vitalii, Babesia spp. and Ehrlichia spp. in dogs in Passo Fundo, state of Rio Grande do Sul, Brazil
}

Rangelia vitalii, Babesia spp. e Ehrlichia spp. em cães de Passo Fundo, estado do Rio Grande do Sul, Brasil

Juliana Gottlieb*; Marcos Rogério André; João Fábio Soares³; Luiz Ricardo Gonçalves²; Mateus Tonial de Oliveira; Marcio Machado Costa ${ }^{4}$; Marcelo Bahia Labruna ${ }^{5}$; Carlos Eduardo Bortolini ${ }^{4}$; Rosangela Zacarias Machado²;

Maria Isabel Botelho Vieira ${ }^{1}$

\author{
${ }^{1}$ Programa de Pós-graduação em Experimentação Animal, Universidade de Passo Fundo - UPF, Passo Fundo, RS, Brasil \\ ${ }^{2}$ Programa de Pós-graduação em Parasitologia, Universidade Estadual Paulista - UNESP, Jaboticabal, SP, Brasil \\ ${ }^{3}$ Universidade de Medicina Veterinária - Unicruz, Cruz Alta, RS, Brasil \\ ${ }^{4}$ Curso de Medicina Veterinária, Universidade de Passo Fundo - UPF, Passo Fundo, RS, Brasil \\ ${ }^{5}$ Programa de Pós-graduação em Epidemiologia Experimental Aplicada à Zoonoses, Departamento de Medicina Veterinária Preventiva e \\ Saúde Animal, Faculdade de Medicina Veterinária e Zootecnia - FMVZ, Universidade de São Paulo - USP, São Paulo, SP, Brasil
}

Received February 1, 2016

Accepted April 27, 2016

\begin{abstract}
Pathogens transmitted by ticks are an emerging problem worldwide, this study aimed to diagnose the causal agents of infection in dogs presenting suspected hemoparasitoses. Fifty-eight dogs with clinical signs such as depression, hemorrhagic diathesis and fever were evaluated regarding clinical presentation, hemogram, blood smears and serological tests, using the indirect immunofluorescence method for the agents Babesia vogeli and Ehrlichia canis and conventional PCR for Babesia spp. (gene $18 \mathrm{~S}$ rRNA), Rangelia vitalii (gene $18 \mathrm{~S}$ rRNA) and Ehrlichia spp. (gene dsb). Five (8.6\%) of the 58 dogs were serologically positive for Babesia spp. and three (5.1\%) for E. canis. Four dogs (6.8\%) were positive for $R$. vitalii through the molecular diagnosis. The PCR products were sequenced and the DNA from $R$. vitalii was found to be $99 \%$ genetically identical to samples of $R$. vitalii that had been isolated in Brazil. No presence of Babesia spp. or $E$. canis was observed through PCR on the dogs evaluated here. The results indicate the presence of $R$. vitalii and exposure to Babesia spp. and Ehrlichia spp. among the dogs analyzed.
\end{abstract}

Keywords: Hemoparasites, piroplasms, sequencing, dogs, nambiuvú, indirect immunofluorescence.

\section{Resumo}

Patógenos transmitidos por carrapatos são um problema emergente em todo o mundo, o trabalho objetivou diagnosticar os agentes causais da infecção em cães com suspeita de hemoparasitoses. Cinquenta e oito caninos com sinais clínicos como depressão, diáteses hemorrágicas e febre foram avaliados quanto à apresentação clínica, hemograma, esfregaço sanguíneo, sorologia pelo método de Imunofluorescência Indireta para os agentes Babesia vogeli e Ehrlichia canis e na PCR convencional para Babesia spp. (gene 18S rRNA), Rangelia vitalii (gene $18 \mathrm{~S}$ rRNA) e Ehrlichia spp. (gene dsb). Cinco $(8,6 \%)$ dos 58 cáes apresentaram sorologia positiva para Babesia spp. e três $(5,1 \%)$ para E. canis. Quatro $(6,8 \%)$ animais mostraram-se positivos para $R$. vitalii no diagnóstico molecular. Os produtos da PCR foram sequenciados e o DNA encontrado de $R$. vitalii mostrou $99 \%$ de identidade genética com amostras de $R$. vitalii isoladas no Brasil. Não foi observada a presença de Babesia spp. e E. canis na PCR dos cães avaliados. Os resultados indicaram a presença de R. vitalii e exposição a Babesia spp. e Ehrlichia spp. entre os cáes analisados.

Palavras-chave: Hemoparasitas, piroplasmídios, sequenciamento, cães, nambiuvú, imunofluorescência indireta. 


\section{Introduction}

Diseases transmitted through the bites of arthropod vectors, such as rangeliosis, ehrlichiosis, babesiosis and anaplasmosis, affect domestic and wild animals around the world, with potential zoonotic risk (BEUGNET \& MARIÉ, 2009; OTRANTO \& DANTAS TORRES, 2010). In this regard, Babesia vogeli and Ehrlichia canis are transmitted to vertebrate hosts by the tick Rhipicephalus sanguineus sensu lato (s.l.) (DANTAS TORRES \& OTRANTO, 2014).

In South America, $R$. vitalii has been reported in domestic dogs in southern and southeastern Brazil (SOARES et al., 2011; MOREIRA et al., 2013), Argentina (EIRAS et al., 2014) and Uruguay (SOARES et al., 2015).

B. vogeli (PASSOS et al., 2005) and Babesia gibsoni (TRAPP et al., 2006) have been detected molecularly in Brazil. $B$. vogeli is the canine babesiosis agent most commonly reported, with seroprevalence ranging from $18.8 \%$ to $73.3 \%$ (TRAPP et al., 2006; FURUTA et al., 2009; SPOLIDORIO et al., 2010). A serological study involving 316 dogs that was conducted in the central region of the state of Rio Grande do Sul, Brazil, showed that only $4.43 \%$ of the animals presented antibodies to $E$. canis according to the indirect fluorescence antibody test (IFAT), although infestation by the tick $R$. sanguineus is common in this region (KRAWCZAK et al., 2012). Seropositivity for the causative agent of canine monocytic ehrlichiosis has been found to range from $0.7 \%$ to $86.2 \%$ among several regions of Brazil (VIEIRA et al., 2013).

Regenerative anemia is frequently observed on hemograms, caused by intravascular and extravascular hemolysis (babesiosis) and exclusively extravascular hemolysis (rangeliosis) (FURLANELLO et al., 2005; FIGHERA, 2007). Thrombocytopenia is a blood abnormality commonly identified in dogs infected with B. canis, E. canis and R. vitalii (FIGHERA, 2007; M'GHIRBI et al., 2009).

Blood smear examinations are useful during the acute phase of the disease, which coincides with the peak level of parasitemia (NEVES, 2000). However, their sensitivity is low because of the morphological similarity seen between agents of the family Anaplasmataceae and piroplasms.

Serological tests form a useful diagnostic method during the chronic phase of hemoparasitosis and in epidemiological surveys. However, they have low specificity, given that they do not distinguish current infection from previous infection (SHAW et al., 2001).

PCR and sequencing of positive samples have proved to be highly sensitive and specific, and are important in establishing a definitive diagnostic method, since the clinical signs involved in hemoparasite infections are clinically very similar (CRIADO-FORNELIO et al., 2003).

The present study aimed to investigate occurrences of diagnoses of infection by Babesia spp., E. canis and R. vitalii in dogs with clinical signs compatible with tick-borne diseases in the Passo Fundo, state of Rio Grande do Sul, Brazil, using hematological, parasitological, serological and molecular methods.

\section{Materials and Methods}

\section{Location and animals of the study}

The study was conducted in the municipality of Passo Fundo, in the northern region of the state of Rio Grande do Sul. The municipality has a total area of $783.4 \mathrm{~km}^{2}$, with approximately 200,000 inhabitants, at a density of 0.26 inhabitants $/ \mathrm{km}^{2}$ (IBGE, 2010).

Fifty-eight dogs that were routinely attended at the veterinary hospital of the University of Passo Fundo (UPF) between January and December 2013, with clinical signs such as depression, hemorrhagic diathesis and fever, were screened so that a clinical evaluation questionnaire could be filled out. The dogs were shaved and, after antisepsis using $70 \%$ alcohol, two samples of venous blood were collected from the jugular vein with the aid of a hypodermic needle coupled to a sterile syringe. One sample was used for a complete hemogram and for performing PCR (1-3 mL, in a sterile flask, with the anticoagulant ethylenediaminetetraacetic acid, EDTA) and the other was used without anticoagulant to perform serological testing by means of indirect immunofluorescence.

\section{Serological and molecular tests and blood-smear examination}

Indirect immunofluorescence kits for the agents $B$. vogeli (dilution 1:40) and E. canis (dilution 1:64), supplied by the Imunodot immunoparasitology laboratory, Jaboticabal, São Paulo, Brazil, were used for the serological diagnosis. The samples were stored in a freezer in the veterinary parasitology laboratory of the UPF veterinary hospital, at a temperature of $-20^{\circ} \mathrm{C}$.

Babesia spp. antigen was prepared by intravenously inoculation of B. vogeli (Jaboticabal strain) into a splenectomized three month-old dog, negative for hemoparasites by PCR and serology (ANDRÉ et al., 2011). Blood smears were performed twice a day to check for the presence of parasites in microscopic examination of Giemsa-stained blood smears. After observing parasitaemia peak on the fifth day after inoculation, infected blood was collected with Alsever solution (113.7 mM glucose, $27.2 \mathrm{mM}$ sodium citrate, $71.8 \mathrm{mM}$ sodium cloride). E. canis antigen was obtained from E. canis (Jaboticabal strain)-infected DH82 cells maintained in culture in the Immunoparasitology Laboratory, UNESP, Jaboticabal, São Paulo (ANDRÉ et al., 2010).

Slides containing air-dried fixed B. vogeli trophozoite-infected blood and E. canis-infected DH82 cells were used in IFAT as previously described (FURUTA et al., 2009; NAKAGHI et al., 2008). Briefly, antigen slides were removed from storage $\left(-20^{\circ} \mathrm{C}\right)$ and allowed to thaw at room temperature for $30 \mathrm{~min}$. Ten microliters of two fold dilutions of sera (cut-off of 1:40 for B. vogeli and 1:64 for E. canis) were placed in wells on antigen slides. Known positive and negative serum samples for the studied agents were obtained from naturally-infected dogs and felids (ANDRÉ et al., 2010, 2011) from Brazil. Slides were incubated at $37^{\circ} \mathrm{C}$ in a moist chamber for $45 \mathrm{~min}$, washed 3 times in PBS (pH 7.2) for $5 \mathrm{~min}$, and air dried at room temperature. FITC-labeled anti-dog (1:32) or anti-cat (1:32) conjugates (Sigma, St. Louis, Missouri) were added to each well. These slides were incubated again at $37^{\circ} \mathrm{C}$, washed 3 times in PBS, once more in distilled water, and air dried at room 
temperature. Next, slides were coversliped, and examined under a fluorescence microscope.

Using sterile hypodermic needles, punctures were made in the internal face of the pinnae of the dogs sampled, in order to obtain peripheral capillary blood. These samples were used to produce four blood smears per dog. The slides were fixed in methanol for two minutes and were then stained using the Giemsa method for 30 minutes. The smears were examined under an optical microscope at a magnification of $1000 \mathrm{x}$.

The blood samples were subjected to DNA extraction using the commercial DNeasy blood and tissue kit (Qiagen ${ }^{\circledR}$, Hilden, Germany), in accordance with the manufacturer's recommendations. The DNA was subjected to a nested PCR assay for Babesia spp., as proposed by Jefferies et al. (2007), in which the oligonucleotide primers BTF1 (5-GGCTCATTACAACAGTTATAG-3), BTR1 (5-CCCAAAGACTTTGATTTCTCTC-3), BTF2 (5-CCGTGCTAATTGTAGGGCTAATAC-3) and BTR2 (GGACTACGACGGTATCTGATCG-3) flanked a fragment of 800 base pairs of the $18 \mathrm{~S}$ rRNA gene. The oligonucleotide primers dsb-330 (5-GATGATGTCTGAAGATATGAAACAAAT-3) and dsb-728 (5-CTGCTCGTCTATTTTACTTCTTAAAGT-3), which flanked a fragment of 409 base pairs of the dsb gene (DOYLE et al., 2005), were used to amplify the DNA of the genus Ehrlichia. The molecular analysis on the microorganisms Babesia spp. and Ehrlichia spp. was performed in the immunoparasitology laboratory at UNESP, Jaboticabal, SP, Brazil. The samples of $R$. vitalii were subjected to PCR using the primer pair BAB143-167 (5-CCG TGCTAA TTG TAG GGCTAA TAC A-3) and BAB694-667 (5-GCT TGA AAC ACT CTARTT TTC TCA AAG-3), which amplify a fragment of approximately 500 base pairs of the $18 \mathrm{~S}$ rRNA gene of piroplasms. The molecular analysis on $R$. vitalii was performed as described by Soares et al. (2011), at the parasitic diseases laboratory of the School of Veterinary Medicine and Zootechnics (FMVZ), University of São Paulo, São Paulo, SP, Brazil. The same reagent concentrations and cycling as described by Jefferies et al. (2007), Doyle et al. (2005) and Smith et al. (2011) were used for the PCR analysis. The PCR products were then transferred onto to $1.5 \%$ agarose gel containing ethidium bromide for electrophoresis. The product was examined under a UV transilluminator (ChemiDoc ${ }^{\mathrm{TM}} \mathrm{MP}$ Imaging System, BIO RAD ${ }^{\circledR}$.

\section{Phylogenetic analysis}

The amplicons were purified using commercial silica bead DNA gel extraction kits (Fermentas ${ }^{\circledR}$, Thermo Fisher Scientific Inc., USA) and were sequenced in an automated sequencer (Applied Biosystems ABI PRISM 3700 DNA Analyzer), following the instructions of the technical manual. The sequences thus obtained were analyzed using BLAST (ALTSCHUL et al., 1990) to determine genetic similarities with the data deposited in GenBank. Partial sequences (541 nucleotides) of the $18 \mathrm{~S}$ rRNA gene derived from the positive samples were aligned with genotypes of the genera Babesia, Rangelia, Theileria, Cytauxzoon and Hepatozoon (obtained from GenBank), using the ClustalWv. 1.8.1 software (THOMPSON et al., 1994). Using the nucleotide substitution model, a maximum likelihood phylogenetic tree was generated by means of the Mega 6.0.6 software (TAMURA et al., 2013) with 100 bootstrap replicates. The substitution model Tamura-Nei+G+I, was selected using the
Mega 6.0.6 software (TAMURA et al., 2013), based on the lowest score of the BIC parameter (Bayesian information criterion). The sequence of Hepatozoon canis was used as an outgroup.

This study was approved by the Ethics Committee for Animal Use of the University of Passo Fundo (CEUA-UPF), under permit no. $003 / 2013$.

\section{Results}

Among the 58 dogs, $49(84.5 \%)$ presented ticks at the time of the clinical evaluation. Depression (81.0\%), anorexia (56.9\%) and emaciation (43.1\%) were the clinical signs most observed among the dogs evaluated (Table 1).

Thrombocytopenia and reduced hematocrit were found in $14(24.1 \%)$ and $28(48.2 \%)$ of the dogs, respectively.

One dog (1.7\%) presented structures suggestive of free piroplasms in the plasma and inside mononuclear cells in the blood smears (Figure 1).

Table 1. Observed frequencies of clinical signs and findings from hemograms, blood smears, serological tests (indirect immunofluorescence test) and PCR among the dogs evaluated.

\begin{tabular}{lcccc}
\hline \multicolumn{1}{c}{ Variables } & Positive & $\mathbf{( \% )}$ & Negative & (\%) \\
\hline Presence of ectoparasites & 49 & 84.5 & 09 & 15.5 \\
Depression & 47 & 81.0 & 11 & 19.0 \\
Anorexia & 33 & 56.9 & 25 & 43.1 \\
Emaciation & 25 & 43.1 & 33 & 56.9 \\
Thrombocytopenia & 14 & 24.1 & 44 & 75.8 \\
Reduced hematocrit & 28 & 48.2 & 30 & 51.7 \\
Blood smear (B. canis) & 1 & 1.7 & 57 & 98.3 \\
Blood smear (E. canis) & - & - & 58 & 100 \\
Blood smear R. vitalii) & - & - & 58 & 100 \\
Serological test (B. canis) & 05 & 8.6 & 53 & 91.3 \\
Serological test (E. canis) & 03 & 5.1 & 55 & 94.8 \\
PCR (R. vitalii) & 04 & 6.8 & 54 & 93.1 \\
PCR (E. canis) & - & - & 58 & 100.0 \\
PCR (B. canis) & - & - & 58 & 100.0 \\
\hline
\end{tabular}

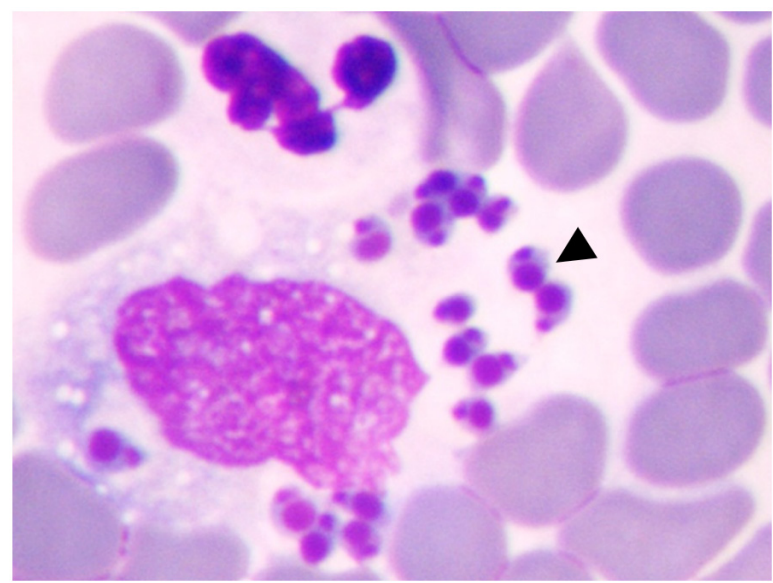

Figure 1. Free structures in the plasma (arrow) and inside a mononuclear cell that were compatible with piroplasms, observed in a Giemsa stained blood smear from a dog. 
Five dogs $(8.6 \%)$ presented anti-B. vogeli antibodies and three $(5.1 \%)$ presented anti-E. canis antibodies in the indirect immunofluorescence test.

Among the 58 dogs sampled, four (6.8\%) were positive for $R$. vitalii according to molecular analysis. These four dogs yielded PCR amplicons that generated DNA sequences that were 99\% genetically identical to samples of $R$. vitalii previously isolated in Brazil, by means of BLAST analysis. Initially, four dogs $(6.8 \%)$ tested positive for Babesia spp. through molecular diagnosis based on the protocol of Jefferies et al. (2007). However, after sequencing of these samples, the amplicons showed identicalness to $R$. vitalii (Figure 2). No other piroplasm organisms were detected in our study. The blood of these four dogs $(6.8 \%)$ that were positive for $R$. vitalii was subjected to PCR and sequencing using two different protocols based on $18 \mathrm{~S}$ rRNA, as described by Jefferies et al. (2007) and Soares et al. (2011).

\section{Discussion}

Out of the 58 dogs evaluated, $84.5 \%$ presented ectoparasites at the time of the clinical examination, presenting clinical signs such as depression, anorexia, emaciation, mucopurulent oculonasal discharge, and hemorrhagic diathesis during evaluation. According to Moraes-Filho et al. (2011), it is possible that more than one species of the $R$. sanguineus complex may be occurring in the Americas. One species might resemble ticks of African origin, with distribution in tropical and subtropical regions of the Americas, while another might resemble European samples, with distribution in temperate regions of southern South America. This hypothesis might explain the absence of dogs positive for E. canis through PCR, among those evaluated here. According to Moraes-Filho et al. (2015), the tick $R$. sanguineus does not have vector capacity for transmitting E. canis.

One of the dogs that showed ectoparasites lived in an urban area but was also kept in the countryside of Rio Grande do Sul during certain times of the year. The findings from this survey may indicate that urban dogs have greater contact with rural settings and wild animals, as a result of processes such as deforestation and the expansion of urban centers, and therefore have greater exposure to the arthropod $A$. aureolatum. It has been speculated that in rural areas of Brazil, wildlife could play an important role as reservoirs of $R$. vitalii (LORETTI \& BARROS, 2005). This parasite has been recently detected through molecular diagnosis in the blood and tissues of the crab-eating fox (Cerdocyon thous) in the northern region of Rio Grande do Sul and in the central and northern regions of the state of São Paulo (SOARES et al., 2014). This suggests that this wild animal may be involved in the lifecycle of $R$. vitalii in the study region (LORETTI \& BARROS, 2005; SOARES et al., 2014). This information corroborates the hypothesis that $R$. vitalii circulates between vertebrate animals and the tick $A$. aureolatum, thus corroborating the results presented here.

Clinical signs such as depression (81.0\%), anorexia (56.9\%) and emaciation (43.1\%) were identified among the dogs evaluated. However, these signs are nonspecific and common to other diseases of dogs. One common clinical manifestation in animals with R. vitalii is hemorrhagic diathesis (FRANÇA et al., 2014), but this

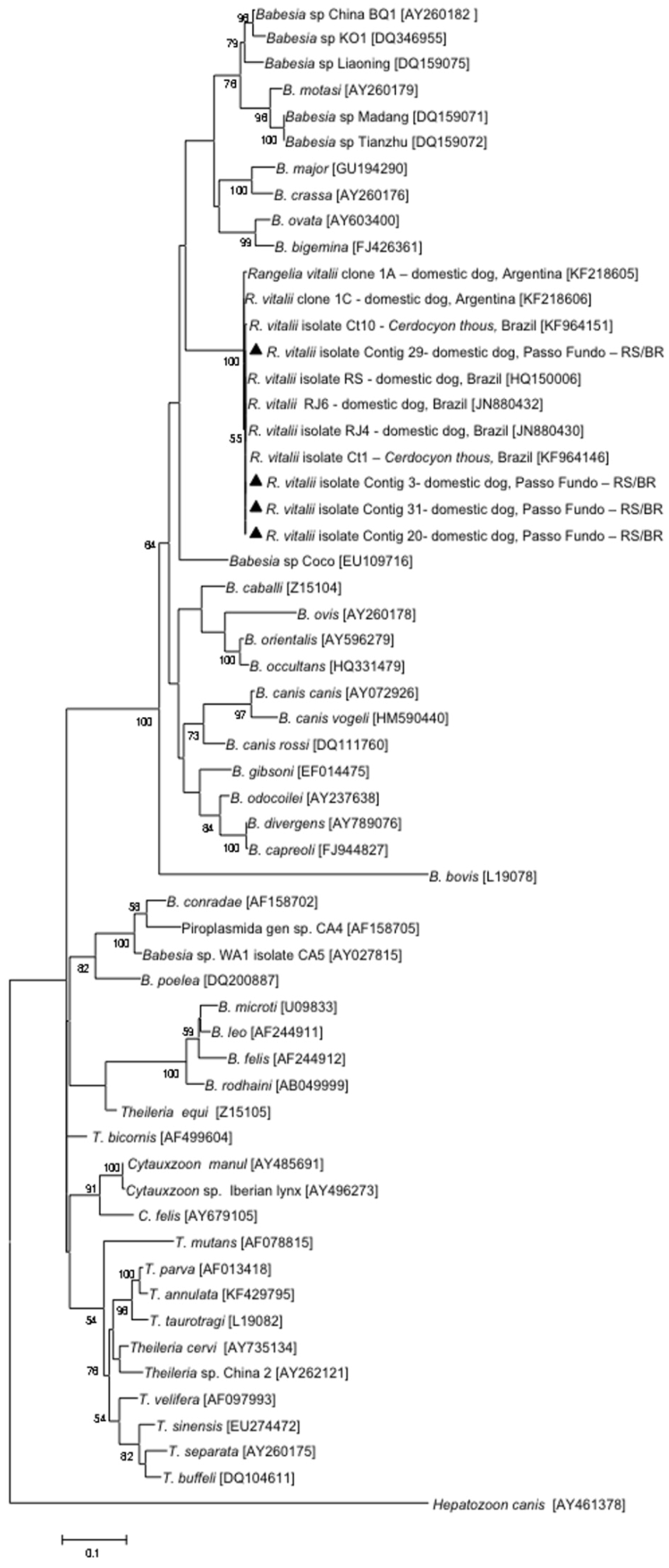

Figure 2. Maximum likelihood phylogenetic tree of $18 \mathrm{~S}$ rRNA partial sequences (541 nucleotides) of Rangelia vitalii and other piroplasms. The $R$. vitalii sequences generated in the present study are indicated by a black arrow head. Numbers on the nodes indicate bootstrap values from 100 replicates. Only bootstrap values $>50$ are shown. Numbers in brackets are GenBank accession numbers. Hepatozoon canis was used as an outgroup. 
was not identified among the dogs samples here. The importance of clinical, epidemiological and laboratory test findings for reaching a definitive diagnosis can be highlighted.

Thrombocytopenia is commonly observed among dogs with hemoparasitosis. Some of the mechanisms involved are splenic sequestration, platelet dysfunction, immune-mediated thrombocytopenia, consumptive thrombocytopenia and decreased platelet aggregation. Regenerative anemia of macrocytic hypochromic type, secondary to intravascular or extravascular hemolytic disorders, along with the presence of thrombocytopenia, aids in making a presumptive diagnosis of hemoparasitosis (PADDOCK \& CHILDS, 2003; FIGHERA, 2007; PAIM et al., 2012). This corroborates the results from the present study, in which $24.1 \%$ of the dogs presented thrombocytopenia and $48.2 \%$ presented reduced hematocrit.

Out of the $6.8 \%$ of the dogs that were positive through PCR for $R$. vitalii, only $1.7 \%$ presented structures compatible with piroplasms in the blood smears (Table 2). These results show that although direct detection by means of parasitological examination of blood smears is a rapid screening technique, it has low sensitivity and specificity. It is therefore only useful in acute cases of hemoparasitosis, at the time of the peak level of parasitemia. The low number of cells parasitized, the level of experience of the microscopist and the small number of blood smears affect the sensitivity of the test (NEVES, 2000; PASSOS et al., 2005).

Out of the $8.6 \%$ of the dogs that presented anti-B. vogeli antibodies, only $1.7 \%$ were positive through PCR for $R$. vitalii. Among the $5.1 \%$ of the dogs with anti-E. canis antibodies, none of them were found to be positive through PCR. Although serological tests are frequently used as a diagnostic method, it is known that several hemoparasite species have antigens in common, thereby giving rise to cross-reactions. This may have occurred in the present study or, furthermore, the dogs may have previously been in contact with agents of the genus Babesia or the family Anaplasmataceae. The serological results for E. canis were similar to those described by Krawczak et al. (2012), who found that only $4.43 \%$ of the dogs were seropositive for this agent in the central region of Rio Grande do Sul. This demonstrated that there was low prevalence of anti-E. canis antibodies, despite the presence of $R$. sanguineus ticks in the dogs. Therefore, interpretations of the serological tests need to be made cautiously, in conjunction with evaluation of the clinical parameters (clinical signs and physical examination) and laboratory parameters, such as the platelet count

Table 2. Blood smears, indirect immunofluorescence tests and PCR on the dogs that were positive for $R$. vitalii through the molecular diagnosis.

\begin{tabular}{|c|c|c|c|}
\hline & & Diagnosis & \\
\hline Animals & $\begin{array}{c}\text { Blood } \\
\text { smears }\end{array}$ & $\begin{array}{c}\text { Indirect immunofluorescence } \\
\text { test for } B \text {. vogeli } \\
\text { and } E \text {. canis } \\
\end{array}$ & PCR \\
\hline $\operatorname{Dog} 7$ & $\mathrm{~N}$ & $\mathrm{~N}$ & R. vitalii \\
\hline $\operatorname{Dog} 17$ & Piroplasms & 1 & R. vitalii \\
\hline $\operatorname{Dog} 51$ & $\mathrm{~N}$ & $\mathrm{~N}$ & R. vitalii \\
\hline Dog 54 & $\mathrm{~N}$ & $\mathrm{~N}$ & R. vitalii \\
\hline
\end{tabular}

$\mathrm{N}$ : negative. 1: B. vogeli. 2: E. canis.
(TABOADA, 1998). Currently, no commercial tests that would allow determination of serum antibody levels specifically against R. vitalii are available in Brazil (FIGHERA, 2007).

The agent most frequently found in the dogs evaluated was $R$. vitalii. The validity of the species $R$. vitalii was frequently confirmed by Soares et al. (2011) through molecular analysis, and the results from their study indicated that this is a reemerging disease. The results highlight the importance of sequencing to determine the definitive diagnosis. The protocol proposed by Jefferies et al. (2007) amplifies a 18S rRNA gene segment, which is common to the species $R$. vitalii and Babesia spp, thus demonstrating that these organisms are phylogenetically related.

The agents found through the molecular diagnosis help to guide clinical management strategies and control measures, and to define the diagnosis. We suggest that further research on this topic should be conducted, particularly with regard to the epidemiology of hemoparasitic diseases, given that the data reported here relate to a portion of the resident dog population that, in theory, receives care and attention from its owners. The results from such evaluations might be different if they involved strays and animals from shelters and/or from animal welfare non-governmental organizations.

$R$. vitalii was identified as infecting domestic dogs in this study, through the molecular diagnosis. This tick-borne pathogen causes disease that often exhibits nonspecific signs and, therefore, molecular diagnostics is a very important tool for conducting specific treatments. These help reduce the adverse effects of some medications, as well as the possible resistance associated with their unnecessary use.

\section{Acknowledgements}

We are grateful to Veridiane da Rosa Gomes and Mariana Dalla Palma for their help in clinical evaluations on the dogs and in blood collection from them. In addition, we acknowledge support received from the Research Support Foundation of the State of Rio Grande do Sul (FAPERGS).

\section{References}

Altschul SF, Gish W, Miller W, Myers EW, Lipman DJ. Basic local alignment search tool. J Mol Biol 1990; 215(3): 403-410. http://dx.doi. org/10.1016/S0022-2836(05)80360-2. PMid:2231712.

André MR, Adania CH, Machado RZ, Allegretti SM, Felippe PAN, Silva $\mathrm{KF}$, et al. Molecular and serologic detection of Ehrlichia spp. in endangered Brazilian wild captive felids. JWildl Dis 2010; 46(3): 1017-1023. http:// dx.doi.org/10.7589/0090-3558-46.3.1017. PMid:20688716.

André MR, Adania CH, Teixeira RH, Allegretti SM, Machado RZ. Molecular and serological detection of Babesia spp. in neotropical and exotic carnivores in Brazilian zoos. J Zoo Wildl Med 2011; 42(1): 139-143. http://dx.doi.org/10.1638/2010-0074.1. PMid:22946386.

Beugnet F, Marié JL. Emerging arthropod-borne diseases of companion animals in Europe. Vet Parasitol 2009; 163(4): 298-305. http://dx.doi. org/10.1016/j.vetpar.2009.03.028. PMid:19403239.

Criado-Fornelio A, Gonzalez-Del-Rio MA, Buling-Saraña A, BarbaCarretero JC. Molecular characterization of Babesia gibsoni isolate from 
Spanish dog. Vet Parasitol 2003; 117(1-2): 123-129. http://dx.doi. org/10.1016/j.vetpar.2003.08.006. PMid:14597285.

Dantas-Torres F, Otranto D. Dogs, cats, parasites and humans in Brazil: opening the Black box. Parasit Vectors 2014; 7(1): 22. http://dx.doi. org/10.1186/1756-3305-7-22. PMid:24423244.

Doyle CK, Labruna MB, Breitschwerdt EB, Tang Y, Corstvet RE, Hegarty BC, et al. Detection of medically important Ehrlichia by quantitative multicolor TaqMan Real-Time Polymerase Chain Reaction of the $d s b$ gene. J Mol Diagn 2005; 7(4): 504-510. http://dx.doi.org/10.1016/ S1525-1578(10)60581-8. PMid:16237220.

Eiras DF, Craviotto MB, Baneth G, Moré G. First report of Rangelia vitalii infection (canine rangeliosis) in Argentina. Parasitol Int 2014; 63(5): 729734. http://dx.doi.org/10.1016/j.parint.2014.06.003. PMid:24970768.

Fighera RA. Rangeliose. Acta Sci Vet 2007; 35(S2): 261-263.

França RT, Silva AS, Loretti AP, Mazzanti CM, Lopes ST. Canine rangeliosis due to Rangelia vitalii: From first report in Brazil in 1910 to current day-A review. Ticks Tick Borne Dis 2014; 5(5): 466-474. http:// dx.doi.org/10.1016/j.ttbdis.2014.04.005. PMid:24950853.

Furlanello T, Fiorio F, Caldin M, Lubas G, Solano-Gallego L. Clinicopathological findings in naturally occurring cases of babesiosis caused by large form Babesia from dogs of northeastern Italy. Vet Parasitol 2005; 134(1-2): 77-85. http://dx.doi.org/10.1016/j.vetpar.2005.07.016. PMid:16112810.

Furuta PI, Oliveira TM, Teixeira MC, Rocha AG, Machado RZ, TinucciCosta MG. Comparison between a soluble antigen-based ELISA and IFAT in detecting antibodies against Babesia canis in dogs. Rev Bras Parasitol Vet 2009; 18(3): 41-45. http://dx.doi.org/10.4322/rbpv.01803007. PMid:19772774.

Instituto Brasileiro de Geografia e Estatística - IBGE. Rio Grande do Sul: Passo Fundo [online]. Rio de Janeiro: IBGE; 2010 [cited 2016 Feb 1]. Available from: http://cidades.ibge.gov.br/xtras/perfil.php? $\operatorname{codmun}=431410 /$

Jefferies R, Ryan UM, Irwin PJ. PCR-RFLP for the detection and differentiation of the canine piroplasm species and its use with filter paper-based technologies. Vet Parasitol 2007; 144(1-2): 20-27. http:// dx.doi.org/10.1016/j.vetpar.2006.09.022. PMid:17127005.

Krawczak FS, Labruna MB, Sangioni LA, Vogel FSF, Soares JF, Lopes STA. Serological survey on Ehrlichia sp. among dogs in the central region of Rio Grande do Sul. Rev Bras Parasitol Vet 2012; 21(4): 415-417. http:// dx.doi.org/10.1590/S1984-29612012005000001. PMid:23184320.

Loretti AP, Barros SS. Hemorrhagic disease in dogs infected with an unclassifield intraendothelial piroplasm in southern Brazil. Vet Parasitol 2005; 134(3-4): 193-213. http://dx.doi.org/10.1016/j.vetpar.2005.07.011. PMid:16153781.

M'Ghirbi Y, Ghorbel A, Amouri M, Nebaoui A, Haddad S, Bouattour A. Clinical, serological, and molecular evidence of ehrlichiosis and anaplasmosis in dogs in Tunisia. Parasitol Res 2009; 104(4): 767-774. http://dx.doi.org/10.1007/s00436-008-1253-4. PMid:19018569.

Moraes-Filho J, Krawczak FS, Costa FB, Soares JF, Labruna MB. Comparative evaluation of the vector competence of four South American populations of the Rhipichephalus sanguineus group for the bacterium Ehrlichia canis, the agent of canine monocytic ehrlichiosis. PLoS One 2015; 10(9): e0139386. http://dx.doi.org/10.1371/journal.pone.0139386. PMid:26414283.
Moraes-Filho J, Marcili A, Nieri-Bastos FA, Richtzenhain LJ, Labruna MB. Genetic analysis of ticks belonging to the Rhipicephalus sanguineus group in Latin America. Acta Trop 2011; 117(1): 51-55. http://dx.doi. org/10.1016/j.actatropica.2010.09.006. PMid:20858451.

Moreira MVL, Guimarães LB, Silva JF, Ocarino NM, Serakides R, Ecco R. Infecção por Rangelia vitalii em um cáo em Minas Gerais. Arch Vet Sci 2013; 18(S2): 637-639.

Nakaghi ACH, Machado RZ, Costa MT, André MR, Baldani CD. Canine ehrlichiosis: clinical, hematological, serological and molecular aspects. Cienc Rural 2008; 38(3): 766-770. http://dx.doi.org/10.1590/ S0103-84782008000300027.

Neves DP. Parasitologia humana. 10th ed. São Paulo: Atheneu; 2000.

Otranto D, Dantas-Torres F. Canine and feline vector-borne diseases in Italy: current situation and perspectives. Parasit Vectors 2010; 3(1): 2. http://dx.doi.org/10.1186/1756-3305-3-2. PMid:20145730.

Paddock CD, Childs JE. Ehrlichia chaffeensis: a prototypical emerging pathogen. Clin Microbiol Rev 2003; 16(1):37-64. http://dx.doi.org/10.1128/ CMR.16.1.37-64.2003. PMid:12525424.

Paim CB, Paim FC, Da Silva AS, França RT, Costa MM, Leal CA, et al. Thrombocytopenia and platelet activity in dogs experimentally infected with Rangelia vitalii. Vet Parasitol 2012; 185(2-4): 131-137. http://dx.doi. org/10.1016/j.vetpar.2011.09.039. PMid:22019200.

Passos LMF, Geiger SM, Ribeiro MFB, Pfister K, Zahler-Rinder M. First molecular detection of Babesia canis vogeli in dogs from Brazil. Vet Parasitol 2005; 127(1): 81-85. http://dx.doi.org/10.1016/j.vetpar.2004.07.028. PMid:15619377.

Shaw SE, Day MJ, Birtles RJ, Breitschwerdt EB. Tick-borne infectious diseases of dogs. Trends Parasitol 2001; 17(2): 74-80. http://dx.doi. org/10.1016/S1471-4922(00)01856-0. PMid:11228013.

Smith SJ, van Aardenne J, Klimont Z, Andres RJ, Volke A, Delgado Arias S. Anthropogenic sulfur dioxide emissions: 1850-2005. Atmos Chem Phys 2011; 11(3): 1101-1116. http://dx.doi.org/10.5194/acp-11-1101-2011.

Soares JF, Carvalho L, Maya L, Dutra F, Venzal JM, Labruna MB. Molecular detection of Rangelia vitalii in domestic dogs from Uruguay. Vet Parasitol 2015; 210(1-2): 98-101. http://dx.doi.org/10.1016/j. vetpar.2015.03.013. PMid:25843009.

Soares JF, Dall'Agnol B, Costa FB, Krawczak FS, Comerlato AT, Rossato B, et al. Natural infection of the wild canid, Cerdocyon thous, with the piroplasmid Rangelia vitalii in Brazil. Vet Parasitol 2014; 202(3-4): 156163. http://dx.doi.org/10.1016/j.vetpar.2014.02.058. PMid:24685025.

Soares JF, Girotto A, Brandão PE, Da Silva AS, França RT, Lopes STA, et al. Detection and molecular characterization of a canine piroplasm from Brazil. Vet Parasitol 2011; 180(3-4): 203-208. http://dx.doi.org/10.1016/j. vetpar.2011.03.024. PMid:21489694.

Spolidorio MG, Labruna MB, Mantovani E, Brandão PE, Richtzenhain LJ, Yoshinari NH. Novel spotted fever group rickettsiosis, Brazil. Emerg Infect Dis 2010; 16(3): 521-523. http://dx.doi.org/10.3201/eid1603.091338. PMid:20202436.

Taboada J. Babesiosis. In: Greene CE, editor. Infectious diseases of the dog and cat. 2nd ed. Philadelphia: WB Saunders; 1998.

Tamura K, Stecher G, Peterson D, Filipski A, Kumar S. MEGA 6: Molecular Evolutionary Genetics Analysis Version 6.0. Mol Biol Evol 2013; 30(12): 2725-2729. http://dx.doi.org/10.1093/molbev/mst197. PMid:24132122. 
Thompson JD, Higgins DG, Gibson TJ. CLUSTAL W: improving the sensitivity of progressive multiple sequence alignment through sequence weighting, position-specific gap penalties and weight matrix choice. Nucleic Acids Res 1994; 22(22): 4673-4680. http://dx.doi.org/10.1093/ nar/22.22.4673. PMid:7984417.

Trapp SM, Dagnone AS, Vidotto O, Freire RL, Amude AM, Morais HS. Seroepidemiology of canine babesiosis and ehrlichiosis in a hospital population. Vet Parasitol 2006; 140(3-4): 223-230. http://dx.doi. org/10.1016/j.vetpar.2006.03.030. PMid:16647817.

Vieira TSWJ, Vieira RFC, Nascimento DAG, Tamekuni K, Toledo RS, Chandrashekar R, et al. Serosurvey of tick-borne pathogens in dogs from urban and rural areas from Parana State, Brazil. Rev Bras Parasitol Vet 2013 22(1): 104-109. http://dx.doi.org/10.1590/S1984-29612013000100019. PMid:24252955. 